\title{
Reductive amination of ketones with ammonium catalyzed by a newly identified Brevibacterium epidermidis strain for the synthesis of $(S)$-chiral amines
}

\author{
Qing-Hua Li a , Yuan Dong ${ }^{b}$, Fei-Fei Chen ${ }^{\text {a }}$, Lei Liu ${ }^{a}$, Chun-Xiu Li a, Jian-He Xua ${ }^{\text {a }}$ Gao-Wei Zheng a,* \\ a State Key Laboratory of Bioreactor Engineering, East China University of Science and Technology, Shanghai 200237, China \\ b Department of Pharmacy, 302 Hospital of People's Liberation Army, Beijing 100039, China
}

\section{A R T I C L E I N F O}

\section{Article history:}

Received 30 April 2018

Accepted 24 May 2018

Published 5 October 2018

\section{Keywords:}

Biocatalysis

Reductive amination

Asymmetric synthesis

Prochiral ketones

Chiral amine

\begin{abstract}
A B S T R A C T
The asymmetric reductive amination of achiral ketones with ammonia is a particularly attractive reaction for the synthesis of chiral amines. Although several engineered amine dehydrogenases have been developed by protein engineering for the asymmetric reductive amination of ketones, they all display $(R)$-stereoselectivity. To date, there is no report of an $(S)$-stereoselective biocatalyst for this reaction. Herein, a microorganism named Brevibacterium epidermidis ECU1015 that catalyzes the $(S)$-selective reductive amination of ketones with ammonium has been successfully isolated from soil. Using B. epidermidis ECU1015 as the catalyst, the asymmetric reductive amination of a set of phenylacetone derivatives was successfully carried out, yielding the corresponding (S)-chiral amines with moderate conversion and $>99 \%$ enantiomeric excess.
\end{abstract}

(C) 2018, Dalian Institute of Chemical Physics, Chinese Academy of Sciences. Published by Elsevier B.V. All rights reserved.

\section{Introduction}

Optically pure amines are an important class of chiral intermediates frequently used in the synthesis of active pharmaceutical ingredients, fine chemicals, and agrochemicals $[1,2]$. For example, approximately $40 \%$ of the drugs approved by the FDA contain one or more chiral amine moieties [3,4]. Due to the prevalent use of chiral amines in organic synthesis, efficient synthetic methods such as the asymmetric reductive amination of ketones and asymmetric reduction of ketimines using transition metal catalysts have been extensively developed [1,2]. However, the direct asymmetric reductive amination of prochiral ketones with ammonia using transition metal catalysts, a key reaction for the synthesis of chiral amines, remains a challenge in industry [5,6]. Moreover, these transition metal-catalyzed processes are usually expensive and unsustainable, often requiring harsh reaction conditions with tedious protection and deprotection steps.

With advances in protein engineering technology, biocatalytic processes have been extensively developed as promising alternatives to traditional chemocatalytic routes for the synthesis of chiral amines owing to their green credentials [7-14]. Numerous biocatalytic routes including (dynamic) kinetic resolution of racemic amines by lipases [15-18], transaminases [19-24], amine oxidases [25-32], and reductive aminases [33]; asymmetric reduction of imines by imine reductases (IREDs) [34-42] and artificial IREDs [43-45]; and asymmetric amination of ketones by IREDs [46-50], transaminases [51-56], re-

\footnotetext{
* Corresponding author. Tel/Fax: +86-21-64250840; E-mail: gaoweizheng@ecust.edu.cn

This work was supported by the National Natural Science Foundation of China $(21472045,21536004)$, and the National Defense Scientific and Technological Innovation Special Zone (17-163-12-ZT-003-055-01).

DOI: 10.1016/S1872-2067(18)63108-0 | http://www.sciencedirect.com/science/journal/18722067 | Chin. J. Catal., Vol. 39, No. 10, October 2018
} 
ductive aminases [57], and amine dehydrogenases (AmDHs) [58-65] have been successfully developed for the synthesis of chiral amines. Among them, the AmDH-catalyzed asymmetric reductive amination of ketones is a particularly attractive route for the direct synthesis of chiral amines because it uses inexpensive ammonia as the amino donor and generates only water as the by-product.

Recently, a wild-type NADH-dependent AmDH from the thermophile Petrotoga mobilis was used for this reductive amination reaction. However, the enzyme only exhibited activity toward aliphatic ketoacids and not aliphatic ketones [66]. Bommarius and co-workers developed two new AmDHs via several rounds of protein engineering using naturally existing amino acid dehydrogenases as scaffolds [58,59]. Subsequently, three other engineered AmDHs, including Rhodococcus Phe-AmDH from Rhodococcus sp. M4 [63], EsLeu-AmDH from Exiguobacterium sibiricum [68], and thermostable Cal-AmDH from Caldalkalibacillus thermarum [65], were developed using the same approach. These engineered AmDHs were used to synthesize a broad set of chiral amines with excellent enantioselectivity by reductive amination of ketones with ammonia. More importantly, two of them have been combined with alcohol dehydrogenases for the synthesis of chiral amines from inexpensive racemic alcohols through elegant hydrogen borrowing dual-enzyme cascade reactions $[67,68]$. Very recently, we successfully expanded the substrate scope of three engineered AmDHs by fine-tuning two key residues surrounding the substrate-binding cavity, thus resulting in steric hindrance for the binding of bulky substrates [69].

However, all these engineered AmDHs display $(R)$-stereoselectivity. Therefore, only $R$-configuration chiral amines can be synthesized from the reductive amination of ketones with ammonia by these enzymes. To date, no $(S)$-stereoselective biocatalyst capable of catalyzing the reductive amination of ketones with ammonia has been reported. Herein, we report the isolation of microbial strains from soil samples able to catalyze the reductive amination of ketones using inexpensive inorganic ammonium as the amine donor for the synthesis of $(S)$-chiral amines.

\section{Experimental}

\subsection{Reagents}

Acetophenone (1a), 3,4-dihydronaphthalen-1(2H)-one (1b), 1-(4-fluorophenyl)propan-2-one ( $p$ FPA) (1d), 1-(4-methoxyphenyl)propan-2-one (1g), 1-(3-fluorophenyl)propan-2-one (1e), 1-(2-fluorophenyl)propan-2-one (S)- $\alpha$-methylbenzylamine, $(R)$ - $\alpha$-methylbenzylamine, $(S, R)-4$ fluoro- $\alpha$-methylphenethylamine, $\quad(R)$-1-(4-methoxyphenyl) propan-2-amine, $(S)$-1-(4-methoxyphenyl)propan-2-amine, and (S)-1,2,3,4-tetrahydronaphthalen-1-amine were purchased from Sigma-Aldrich (Tianjin, China). All the other chemicals used were of analytical grade and commercially available. ${ }^{1} \mathrm{H}$ and ${ }^{13} \mathrm{C}$ NMR spectra were recorded on a Bruker Avance 400 $\mathrm{MHz}$ spectrometer.

\subsection{Screening of microbial strains}

Different soil samples were collected from nature and enriched using the following medium at $30{ }^{\circ} \mathrm{C}$ for $48 \mathrm{~h}$. Enrichment medium (per liter): $(S)-\alpha$-methylbenzylamine, $0.6 \mathrm{~g}$ (5 mmol); glycerol, 2.0 g; $\mathrm{KH}_{2} \mathrm{PO}_{4}, 3.0 \mathrm{~g}$; NaCl, $1.0 \mathrm{~g}$; $\mathrm{MgSO}_{4} \cdot 7 \mathrm{H}_{2} \mathrm{O}$, $0.5 \mathrm{~g}$; and trace elements; $\mathrm{pH}$ 7.0. The single strain isolated was initially screened for the deamination of (S)- $\alpha$-methylbenzylamine. The reaction mixture for deamination contained $5 \mathrm{mmol} / \mathrm{L}(S)$ - $\alpha$-methylbenzylamine, wet cells from $4 \mathrm{~mL}$ cultured broth, and $0.5 \mathrm{~mL}$ glycine- $\mathrm{NaOH}$ buffer $(0.2$ mol/L, pH 10.0). The reaction was carried out at $30{ }^{\circ} \mathrm{C}$ and $1000 \mathrm{r} / \mathrm{min}$ for $24 \mathrm{~h}$, and the products were analyzed by TLC. The strains producing acetophenone were rapidly identified and further screened for the reductive amination of acetophenone with ammonia. The reaction mixture for amination contained $5 \mathrm{mM}$ acetophenone, wet cells from $4 \mathrm{~mL}$ cultured broth, $1 \mathrm{~mol} / \mathrm{L} \mathrm{NH}_{4} \mathrm{Cl}$, and $0.5 \mathrm{~mL}$ Tris-HCl buffer (0.2 mol/L, pH 8.0), which was shaken at $30{ }^{\circ} \mathrm{C}$ for $24 \mathrm{~h}$. The products extracted from the reaction mixture were identified by GC.

\subsection{Identification of the best strain}

For the identification of the microorganism, the $16 \mathrm{~S}$ rDNA gene was amplified via the polymerase chain reaction (PCR) with the universal primer pair AGAGTTTGATCCTGGCTCAG and GGTTACCTTGTTACGACTT. The sequence was analyzed with the Basic Local Alignment Search Tool (BLAST). In order to identify the organism from the $16 \mathrm{~S}$ rDNA gene sequence, the phylogenetics and molecular evolutionary genetics were constructed using the Clustal Omega and MEGA version 6.06 software. According to the $16 \mathrm{~S}$ rDNA sequence of strain Es11, it was identified as Brevibacterium epidermidis ECU1015.

\subsection{Cultivation of B. epidermidis ECU1015}

B. epidermidis ECU1015 was grown aerobically at $30{ }^{\circ} \mathrm{C}$ for $24 \mathrm{~h}$ in an optimized medium with the following composition (per liter): glycerol, $10.0 \mathrm{~g}$; peptone, $5.0 \mathrm{~g}$; yeast extract, $5.0 \mathrm{~g}$; $\mathrm{NaCl}, 1.0$ g; $\mathrm{KH}_{2} \mathrm{PO}_{4}, 0.5 \mathrm{~g}$; and $\mathrm{MgSO}_{4}, 0.2 \mathrm{~g}$; $\mathrm{pH}$ 7.0. After cultivation, the cells were harvested by centrifugation $(8000 \mathrm{r} / \mathrm{min}$, $10 \mathrm{~min}$ ) and washed twice with physiological saline.

\subsection{Effects of different parameters on the B. epidermidis ECU1015 activity toward reductive amination}

\subsubsection{Effect of inorganic ammonium concentration}

The effect of the concentration of inorganic ammonium on the reductive amination catalyzed by B. epidermidis ECU1015 whole cells was studied at different concentrations of $\mathrm{NH}_{4} \mathrm{Cl}$. The reaction mixture $(1 \mathrm{~mL})$ contained $5 \mathrm{mmol} / \mathrm{L} p$ FPA (1d), different concentrations of $\mathrm{NH}_{4} \mathrm{Cl}$ ranging from 0 to $2 \mathrm{~mol} / \mathrm{L}$, $100 \mathrm{~g} / \mathrm{L}$ wet cells of B. epidermidis, $4 \%(\mathrm{v} / \mathrm{v})$ DMSO, and potassium phosphate sulfate (KPB) $(0.2 \mathrm{~mol} / \mathrm{L}, \mathrm{pH} 7.5)$. The reactions were performed at $30{ }^{\circ} \mathrm{C}$ and $1000 \mathrm{r} / \mathrm{min}$ for $24 \mathrm{~h}$. The samples were treated by addition of $100 \mu \mathrm{L} \mathrm{NaOH}(10 \mathrm{~mol} / \mathrm{L})$ and extracted with dichloromethane $(600 \mu \mathrm{L})$. The organic 
layer was dried over anhydrous sodium sulfate. The concentration and enantiomeric excess $(e e)$ of the products were determined by GC analysis.

\subsubsection{Effect of $p H$ and temperature}

To study the effect of the $\mathrm{pH}$ on the $B$. epidermidis ECU1015-catalyzed reductive amination reaction, the experiments were performed at different initial $\mathrm{pH}$ values at $30{ }^{\circ} \mathrm{C}$ for $24 \mathrm{~h}$. The reaction mixture included $0.5 \mathrm{~mL}$ whole-cells containing $100 \mathrm{~g} / \mathrm{L}$ wet cells of B. epidermidis, $5 \mathrm{mmol} / \mathrm{L} p \mathrm{FPA}$, $1.25 \mathrm{~mol} / \mathrm{L} \mathrm{NH}_{4} \mathrm{Cl}, 4 \%(v / v)$ DMSO, and different buffers with $\mathrm{pH}$ values ranging from 6.0 to 10.0 : $\mathrm{KPB}$ ( $\mathrm{pH} 6.0$ to 7.5 ), Tris-HCl (pH 7.5 to 9.0), and glycine- $\mathrm{NaOH}$ (pH 9.0 to 10.0).

The effect of the temperature was studied by running experiments at different temperatures ranging from 25 to $40{ }^{\circ} \mathrm{C}$ for $24 \mathrm{~h}$. The reaction mixture was composed of $100 \mathrm{~g} / \mathrm{L}$ wet cells of B. epidermidis, $5 \mathrm{mM} p \mathrm{FPA}, 1.25 \mathrm{~mol} / \mathrm{L} \mathrm{NH}_{4} \mathrm{Cl}, 4 \%(\mathrm{v} / \mathrm{v})$ DMSO, and $0.5 \mathrm{~mL} \mathrm{KPB} \mathrm{(0.2} \mathrm{mol/L,} \mathrm{pH} \mathrm{7.5).}$

The samples were treated by addition of $0.1 \mathrm{~mL} \mathrm{NaOH}(10$ $\mathrm{mol} / \mathrm{L})$ and then extracted with dichloromethane $(600 \mu \mathrm{L})$. The organic layer was dried over anhydrous sodium sulfate. The concentration and $e e$ of the products were determined by GC analysis.

\subsubsection{Effect of substrate concentration}

To research the effect of the substrate concentration on the reductive amination reaction, experiments with mixtures containing $100 \mathrm{~g} / \mathrm{L}$ wet cells of B. epidermidis, $1.25 \mathrm{~mol} / \mathrm{L} \mathrm{NH} \mathrm{N}_{4} \mathrm{Cl}$, $4 \%(v / v)$ DMSO, $p$ FPA at concentrations ranging from 5 to 30

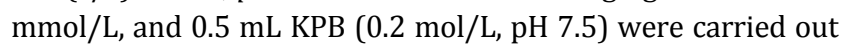
at $30^{\circ} \mathrm{C}$ for $24 \mathrm{~h}$.

\subsection{Reductive amination of selected ketones catalyzed by $B$. epidermidis ECU1015 under optimized conditions}

Mixtures composed of $10 \mathrm{mmol} / \mathrm{L}$ of ketone (1a-1e), 1.25 $\mathrm{mol} / \mathrm{L} \mathrm{NH}_{4} \mathrm{Cl}, 100 \mathrm{~g} / \mathrm{L}$ wet cells of B. epidermidis, $4 \%(\mathrm{v} / \mathrm{v})$

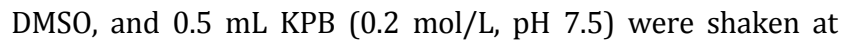
$1000 \mathrm{r} / \mathrm{min}$ in sealed $2 \mathrm{~mL}$ tubes at $30^{\circ} \mathrm{C}$ for $24 \mathrm{~h}$. The samples were treated by addition of $0.1 \mathrm{~mL} \mathrm{NaOH}(10 \mathrm{~mol} / \mathrm{L})$, and then extracted with dichloromethane $(600 \mu \mathrm{L})$. The organic layer was dried over anhydrous sodium sulfate. The substrate conversion and product ee were determined by GC analysis.

\subsection{Preparation of (S)-4-fluoro- $\alpha$-methylphenethylamine by $B$. epidermidis-catalyzed reductive amination}

Wet cells of B. epidermidis ECU1015 (10 g), $152 \mathrm{mg}$ 1d (10 $\mathrm{mmol} / \mathrm{L}), 1.25 \mathrm{~mol} / \mathrm{L} \mathrm{NH}_{4} \mathrm{Cl}, 4 \%(v / v)$ DMSO, and $100 \mathrm{~mL} \mathrm{KPB}$ $(0.2 \mathrm{~mol} / \mathrm{L}, \mathrm{pH} 7.5)$ were mixed in a $250-\mathrm{mL}$ round bottom flask. The reaction mixture was shaken in an incubator at $30^{\circ} \mathrm{C}$. The reaction was monitored by GC. When the conversion reached a plateau, the reaction mixture was acidified to $\mathrm{pH} 2.0$ by addition of $\mathrm{HCl}(1 \mathrm{~mol} / \mathrm{L})$. The water layer was washed with $100 \mathrm{~mL} \mathrm{CH}_{2} \mathrm{Cl}_{2}$ to remove any unreacted ketone, the $\mathrm{pH}$ adjusted to $12.0-14.0$ using $\mathrm{NaOH}(10 \mathrm{~mol} / \mathrm{L})$, and extracted with $100 \mathrm{~mL} \mathrm{CH}_{2} \mathrm{Cl}_{2}$. The organic fractions containing the amine product were dried over anhydrous $\mathrm{Na}_{2} \mathrm{SO}_{4}$ and concentrated. An ethereal solution of $\mathrm{HCl}(2 \mathrm{~mol} / \mathrm{L}, 2 \mathrm{~mL})$ was added to the remaining product to precipitate the corresponding amine hydrochloride. The precipitate was dried under reduced pressure to afford the corresponding amine hydrochloride.

\subsection{GC analysis}

Conversion analysis: the substrate conversion was determined with a GC-2014 gas chromatograph (Shimadzu, Tokyo, Japan) equipped with an FID detector and a DB-1701 column (Agilent, $30 \mathrm{~m} \times 0.25 \mathrm{~mm} \times 0.25 \mu \mathrm{m}$ ) using $\mathrm{N}_{2}$ as the carrier gas. $n$-Dodecane was used as the internal standard. The injector and detector temperatures were set to 250 and $280^{\circ} \mathrm{C}$, respectively. The initial column temperature of $120^{\circ} \mathrm{C}$ was held for $2 \mathrm{~min}$, raised to $150{ }^{\circ} \mathrm{C}$ at a rate of $10^{\circ} \mathrm{C} / \mathrm{min}$ and held for $1 \mathrm{~min}$, then raised to $200{ }^{\circ} \mathrm{C}$ at a rate of $20^{\circ} \mathrm{C} / \mathrm{min}$, and finally held for 15 $\min$.

Enantiomeric excess analysis: The samples were first derivatized by adding pyridine $(2 \mu \mathrm{L})$ and acetic anhydride $(5 \mu \mathrm{L})$ at room temperature for $30 \mathrm{~min}$, and then characterized by GC-2014 gas chromatography (Shimadzu, Tokyo, Japan) equipped with an FID detector and a CP-Chiral-DEX CB column (Agilent, $25 \mathrm{~m} \times 0.25 \mathrm{~mm} \times 0.25 \mu \mathrm{m}$ ) using $\mathrm{N}_{2}$ as the carrier gas. The injector and detector temperatures were both set to 280 ${ }^{\circ} \mathrm{C}$. The initial column temperature of $70{ }^{\circ} \mathrm{C}$ was held for $2 \mathrm{~min}$, raised to $120^{\circ} \mathrm{C}$ at a rate of $20^{\circ} \mathrm{C} / \mathrm{min}$ and held for $2 \mathrm{~min}$, then raised to $160^{\circ} \mathrm{C}$ at a rate of $10^{\circ} \mathrm{C} / \mathrm{min}$ and held for $2 \mathrm{~min}$, and finally raised to $180{ }^{\circ} \mathrm{C}$ at a rate of $10{ }^{\circ} \mathrm{C} / \mathrm{min}$ and held for 2 min.

\section{Results and discussion}

\subsection{Identification of the best strain}

Initially, various microorganisms were isolated from soil samples through enrichment culturing using $(S)$ - $\alpha$-methylbenzylamine $((S)-\alpha$-MBA) as the sole nitrogen source. The strains showing clear formation of acetophenone on the silica gel plates by TLC analysis were selected and further examined for amination activity, using acetophenone (Scheme 1, 1a) as the model substrate in the presence of inorganic ammonium. Among them, two candidate strains were

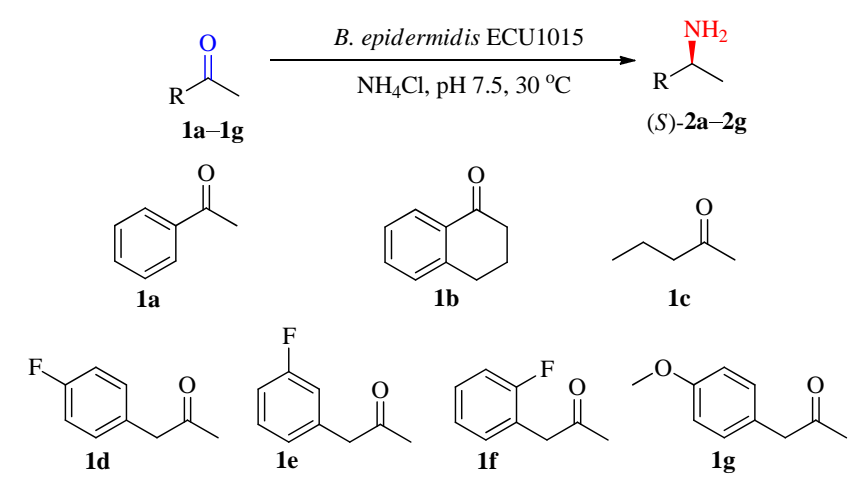

Scheme 1. Reductive amination of selected ketones 1a-1g catalyzed by B. epidermidis ECU1015. 
Table 1

Reductive amination of $\mathbf{1 a}$ and $\mathbf{1 d}$ with ammonia using two candidate strains.

\begin{tabular}{lccc}
\hline Substrate & Strain & Conversion $^{\mathrm{a}}(\%)$ & $e^{\mathrm{b}}(\%)$ \\
\hline 1a & Strain Es11 & 7.4 & $>99(S)$ \\
1a & Strain Fm98 & 6.2 & $>99(S)$ \\
1d & Strain Es11 & 36.0 & $>99(S)$ \\
1d & Strain Fm98 & 8.6 & $>99(S)$ \\
\hline
\end{tabular}

a Determined by GC (DB-1701 column);

b Determined by GC (CP-Chiral-DEX column).

found to catalyze the reductive amination of 1a to (S)- $\alpha$-MBA with $>99 \% e e$, albeit with low conversion (Table 1). Moreover, these two candidate strains could also convert $p$ FPA (1d) into the corresponding $(S)$-4-fluoro- $\alpha$-methylphenethylamine with $>99 \%$ ee (Table 1). In this reaction, strain Es11 yielded a higher conversion than strain Fm98 and was therefore chosen for further studies. Strain Es11 was subsequently identified as Brevibacterium epidermidis ECU1015 by 16 S rDNA sequencing and hereafter designated as B. epidermidis ECU1015.

\subsection{Effect of amino donors and ammonium concentration on $B$. epidermidis-catalyzed reductive amination}

To choose the most suitable amino donors, we first examined the effect of different amino compounds on the synthesis of (S)- $p$ FPAm from $p$ FPA. As shown in Fig. 1(a), using $\mathrm{NH}_{4} \mathrm{Cl}$ as the amino donor, the reaction afforded the highest product yield. Therefore, $\mathrm{NH}_{4} \mathrm{Cl}$ was selected as the amino donor for the reductive amination reactions.

Subsequently, different concentrations of $\mathrm{NH}_{4} \mathrm{Cl}$ ranging from 0.25 to $2.0 \mathrm{~mol} / \mathrm{L}$ were used for the amination of substrate $p$ FPA to investigate the effect of the $\mathrm{NH}_{4}{ }^{+}$concentration on the reductive amination activity of $B$. epidermidis. As shown in Fig. 1(b), the concentration of the product (S)-4-fluoro- $\alpha$-methylphenethylamine is strongly affected by the $\mathrm{NH}_{4}+$ concentration. The concentration of the product increased with the $\mathrm{NH}_{4}{ }^{+}$concentration and then decreased at ionic concentrations greater than $1.25 \mathrm{~mol} / \mathrm{L}$. In general, the enzymes used for the reductive amination of achiral ketones such as amine dehydrogenases [66-69] display poor affinity toward ammonia. Therefore, the supra-stoichiometric addition of ammonia is necessary to drive the reaction equilibrium in the desired direction. For example, Carine Vergne-Vaxelaire and co-workers identified a natural amine dehydrogenase from Petrotoga mobilis. The enzyme catalyzed the transformation of 4-ketopentanoic acid (10 mmol/L) to 4-aminopentanoic acid using $5 \mathrm{~mol} / \mathrm{L}$ free ammonia as the amine donor [64]. Therefore, $1.25 \mathrm{~mol} / \mathrm{L}$ was chosen as the optimal $\mathrm{NH}_{4}{ }^{+}$concentration for the reductive amination of $p$ FPA by $B$. epidermidis.

\subsection{Effect of $p H$ and temperature on B. epidermidis-catalyzed reductive amination}

To determine the optimal $\mathrm{pH}$, the B. epidermidis-catalyzed reductive amination of $p$ FPA was conducted at $\mathrm{pH}$ values ranging from 6.0 to 10.0. As shown in Fig. 2(a), the highest product concentration was obtained at $\mathrm{pH}$ 7.5. Thus, $\mathrm{pH} 7.5$ was chosen as the optimal $\mathrm{pH}$ for the asymmetric reductive amination of $p$ FPA by B. epidermidis.

Similarly, the effect of temperature $\left(25-40{ }^{\circ} \mathrm{C}\right)$ was also studied. The concentration of the product formed increased with temperature from 25 to $30^{\circ} \mathrm{C}$ to then decrease at higher temperatures (Fig. 2(b)). Hence, $30{ }^{\circ} \mathrm{C}$ was chosen as the optimum reaction temperature for the asymmetric reductive amination reaction catalyzed by $B$. epidermidis.

\subsection{Effect of substrate concentration on the $B$. epidermidis-catalyzed reductive amination}

The substrate concentration was also found to have a significant effect on the asymmetric reductive amination catalyzed by $B$. epidermidis. Therefore, the reductive amination reaction was carried out for $24 \mathrm{~h}$ at different substrate concentrations. As shown in Fig. 3, the concentration of the product increased with the substrate concentration up to $10 \mathrm{mmol} / \mathrm{L}$, after which it decreased. Therefore, $10 \mathrm{mmol} / \mathrm{L}$ was chosen as the optimal substrate concentration.
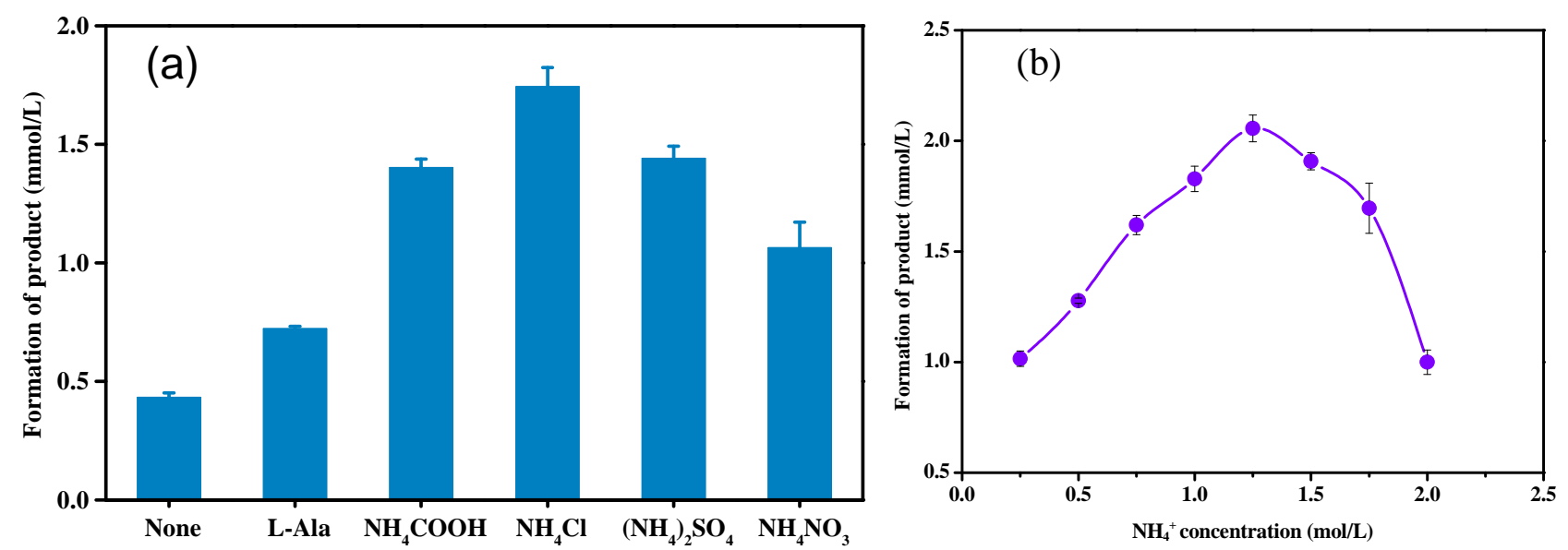

Fig. 1. Effect of amino donor (a) and $\mathrm{NH}_{4}{ }^{+}$concentration (b) on reductive amination of $p$ FPA by B. epidermidis. 

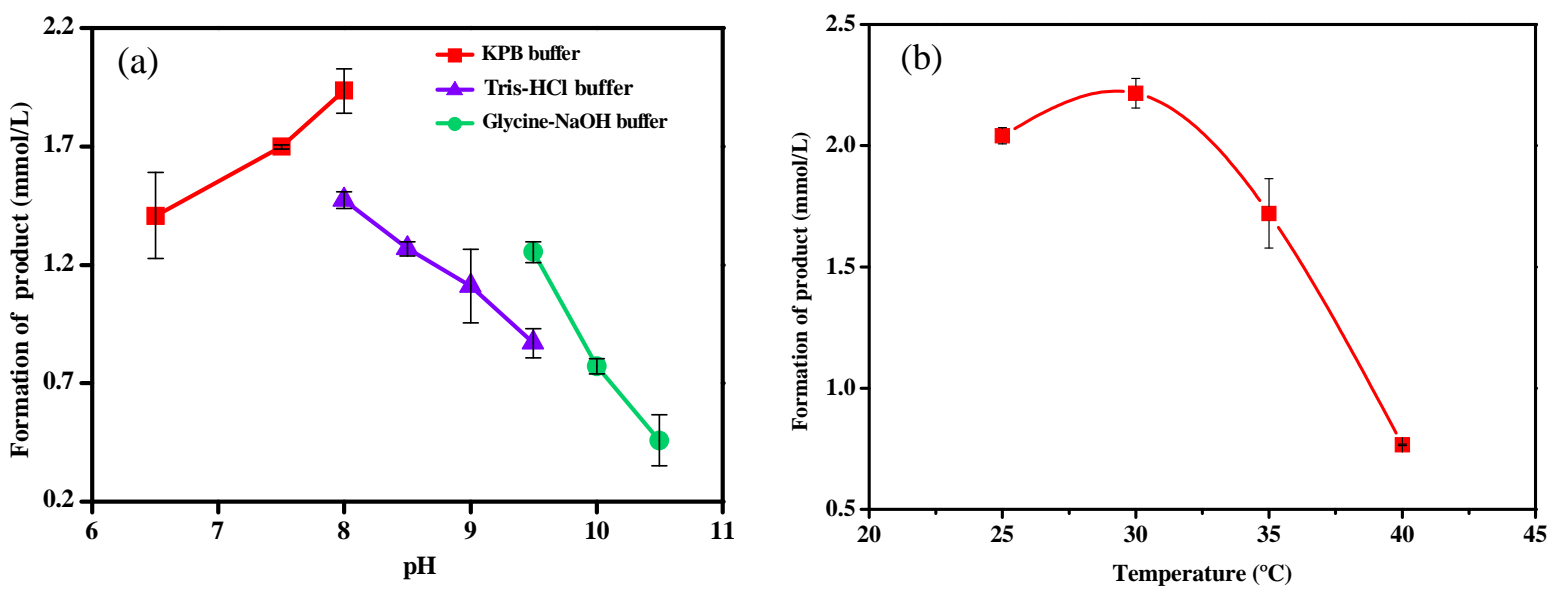

Fig. 2. Effect of $\mathrm{pH}(\mathrm{a})$ and temperature (b) on reductive amination of $p$ FPA. The reaction was performed using the conditions for the $p$ FPAm synthesis, except that the initial $\mathrm{pH}$ of the reaction mixture at $30^{\circ} \mathrm{C}$ (a) and the reaction temperature (b) were varied as indicated in the figures.

\subsection{Substrate scope for reductive amination by B. epidermidis}

Under the optimal reaction conditions, the asymmetric reductive amination of a range of ketones (Scheme 1, 1a-1g) catalyzed by B. epidermidis ECU1015 was investigated, and the results are shown in Table 2. For acetophenone 1a, B. epidermidis ECU1015 exhibited very low reactivity, affording only 9.7\% conversion (Table 2, entry 1), while no measurable reactivity for bulky substrate 1b was observed, suggesting that the steric hindrance of this bulky substrate severely hampers its transformation. In addition, B. epidermidis exhibited almost no activity toward aliphatic ketone 1c. Pleasingly, B. epidermidis ECU1015 displayed higher activity toward $p a-$ ra-fluorophenylacetone 1d bearing a more electron-withdrawing substituent than acetophenone 1a, whereby $53 \%$ of 1 d was converted into the corresponding (S)-amine with $>99 \%$ ee within $30 \mathrm{~h}$ (Table 2, entry 4), suggesting that electron-withdrawing substituents may activate the carbonyl carbon of the substrates $[70,71]$. Subsequently, other phe-

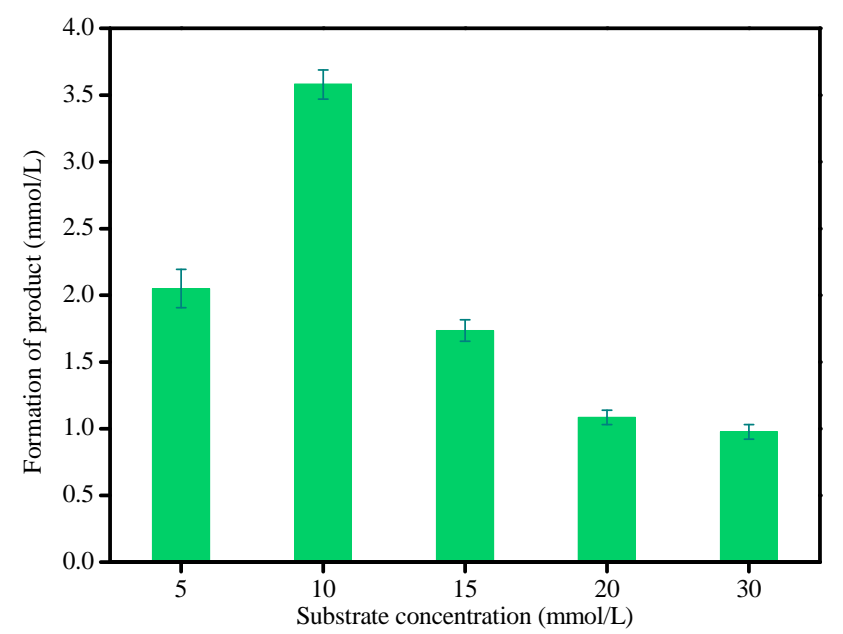

Fig. 3. Effect of substrate concentration on reductive amination of $p$ FPA by $B$. epidermidis. nylacetone derivatives such as meta-, ortho-fluoro-, and para-methoxy-substituted phenylacetones $\mathbf{1 e - 1 g}$ were examined. Conversions of $45 \%-68 \%$ were achieved in the B. epidermidis-catalyzed reductive amination of $\mathbf{1 e - 1 g}$ and the corresponding chiral amines were obtained in $>99 \%$ ee with (S)-selectivity (Table 2, entries 5-7). The moderate conversions are possibly caused by poor expression of the target enzyme in the natural host. Therefore, it should be possible to further increase the conversion using recombinant enzymes or highly active engineered mutants in the future.

\subsection{Preparation of (S)-4-fluoro- $\alpha$-methylphenethylamine}

The reductive amination product of substrate 1d, $(S)$-4-fluoro- $\alpha$-methylphenethylamine, is an important chiral building block for the synthesis of human adenosine receptor agonists [72]. To assess the feasibility of this process, 1d was subjected to preparative synthesis at $100 \mathrm{~mL}$ reaction scale. The resulting time-course (Fig. 4) shows that the substrate was converted into optically pure $(S)$-4-fluoro- $\alpha$ - methylphenethylamine with $50 \%$ conversion and $>99 \%$ ee within $36 \mathrm{~h}$. After extraction and normal work-up, $58.3 \mathrm{mg}$ of (S)-4-fluoro- $\alpha$-methylphenethylamine hydrochloride was isolated in $30.6 \%$ yield and $>99 \%$ ee.

Table 2

Reductive amination of ketones 1a-1g by B. epidermidis ECU1015.

\begin{tabular}{lcccc}
\hline Entry & Substrate & $\begin{array}{c}\text { Time } \\
(\mathrm{h})\end{array}$ & $\begin{array}{c}\text { Conversion } \\
(\%)\end{array}$ & $e e^{\mathrm{b}}(\%)$ \\
\hline 1 & $\mathbf{1 a}$ & 48 & 9.7 & $>99(S)$ \\
2 & $\mathbf{1 b}$ & 48 & n.m. & n.m. \\
3 & $\mathbf{1 c}$ & 48 & n.m. & n.m. \\
4 & $\mathbf{1 d}$ & 30 & 53 & $>99(S)$ \\
5 & $\mathbf{1 e}$ & 30 & 45 & $>99(S)$ \\
6 & $\mathbf{1 f}$ & 30 & 49 & $>99(S)$ \\
7 & $\mathbf{1 g}$ & 30 & 68 & $>99(S)$ \\
\hline
\end{tabular}

a Determined by GC (DB-1701 column);

b Determined by GC (CP-Chiral-DEX column); c No measurable activity. 


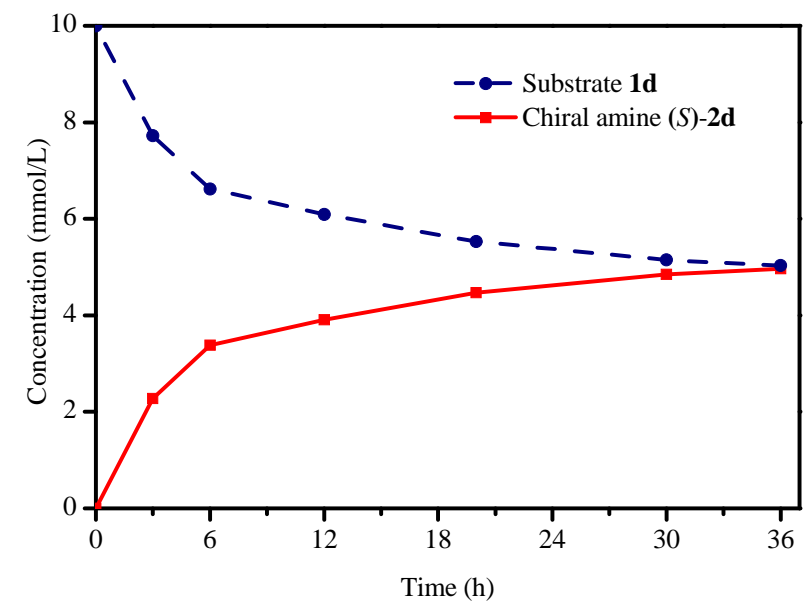

Fig. 4. Time course of reductive amination of $p$ FPA (1d) catalyzed by $B$. epidermidis ECU1015.

\section{Conclusions}

We have identified and characterized a new strain, namely B. epidermidis ECU1015, able to catalyze the reductive amination of ketones using inorganic ammonium as the amino donor to generate the corresponding $(S)$-chiral amines. The desired product $(S)$ - $p$ FPAm was obtained in enantiomeric excess of
$99 \%$ and yield of $30.6 \%$ after process optimization. In addition, a range of $(S)$-aryl amines were synthesized by biocatalytic reductive amination of the corresponding ketones. Thus, $B$. epidermidis ECU1015 has been demonstrated to be a very promising biocatalyst for the asymmetric synthesis of $(S)$-chiral amines.

\section{References}

[1] H. A. Wittcoff, B. G. Rueben, J. S. Plotkin, Industrial Organic Chemicals, 2nd ed., Wiley, New Jersey, 2004, 544-549.

[2] T. C. Nugent, Chiral Amine Synthesis: Methods, Developments and Applications, Wiley-VCH, Weinheim, Germany, 2010, XVII-XVIII.

[3] L. M. Jarvis, Chem. Eng. News, 2016, 94, 12-17.

[4] D. Ghislieri, N. J. Turner, Top. Catal., 2014, 57, 284-300.

[5] D. J. C. Constable, P. J. Dunn, J. D. Hayler, G. R. Humphrey, J. L. Leazer Jr., R. J. Linderman, K. Lorenz, J. Manley, B. A. Pearlman, A. Wells, A. Zaks, T. Y. Zhang, Green Chem., 2007, 9, 411-420.

[6] J. B. Wang, M. T. Reetz, Nat. Chem., 2015, 7, 948-949.

[7] G. Grogan, Curr. Opin. Chem. Biol., 2018, 43, 15-22.

[8] J. H. Schrittwieser, S. Velikogne, M. Hall, W. Kroutil, Chem. Rev., 2018, 118, 270-348.

[9] H. Kohls, F. Steffen-Munsberg, M. Hohne, Curr. Opin. Chem. Biol., 2014, 19, 180-192.

[10] J. M. Woodley, Curr. Opin. Chem. Biol., 2013, 17, 310-316.

\section{Graphical Abstract}

Chin. J. Catal., 2018, 39: 1625-1632 doi: 10.1016/S1872-2067(18)63108-0

Reductive amination of ketones with ammonium catalyzed by a newly identified Brevibacterium epidermidis strain for the synthesis of $(S)$-chiral amines

Qing-Hua Li, Yuan Dong, Fei-Fei Chen, Lei Liu, Chun-Xiu Li, Jian-He Xu, Gao-Wei Zheng*

East China University of Science and Technology; 302 Hospital of People's Liberation Army

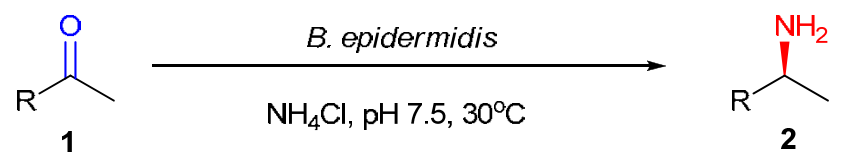<smiles>C[C@H](N)c1ccccc1</smiles>

$9.7 \%$ conv $>99 \%$ ee<smiles>C[C@H](N)Cc1ccccc1F</smiles>

$49 \%$ conv. $>99 \%$ ee<smiles>C[C@H](N)Cc1ccc(F)cc1</smiles>

\section{$53 \%$ conv.} $>99 \%$ ee<smiles>C[C@H](N)Cc1cccc(F)c1</smiles>

$45 \%$ conv. $>99 \%$ ee<smiles>COc1ccc(C[C@H](C)N)cc1</smiles>

$68 \%$ conv. $>99 \%$ ee

The new strain Brevibacterium epidermidis ECU1015 can catalyze the reductive amination of ketones using inorganic ammonium as the amino donor to generate the corresponding $(S)$-chiral amines with high enantiomeric excess $(e e>99 \%)$. A range of $(S)$-aryl amines were synthesized via biocatalytic reductive amination of ketones. 
[11] Z. Chen, A. P. Zeng, Curr. Opin. Biotechnol., 2016, 42, 198-205.

[12] J. H. Schrittwieser, S. Velikogne,W. Kroutil, Adv. Synth. Catal., 2015, 357, 1655-1685.

[13] J. Lalonde, Curr. Opin. Biotechnol., 2016, 42, 152-158.

[14] G. W. Zheng, J. H. Xu, Curr. Opin. Biotechnol., 2011, 22, 784-792.

[15] F. Balkenhohl, K. Ditrich, B. Hauer, W. Ladner, J. Prakt. Chem., 1997, 339, 381-384.

[16] Á. Mourelle-Insua, M. López-Iglesias, V. Gotor, V. Gotor-Fernández, J. Org. Chem., 2016, 81, 9765-9774.

[17] A. S. de Miranda, L. S. M. Mirand, R. O. M. A. de Souza, Biotechnol. Adv., 2015, 33, 372-393.

[18] O. Verho, J. E. Bäckvall, J. Am. Chem. Soc., 2015, 137, 3996-4009.

[19] D. Koszelewski, K. Tauber, K. Faber, W. Kroutil, Trends Biotechnol., 2010, 28, 324-332.

[20] M. D. Truppo, N. J. Turner, J. D. Rozzell, Chem. Commun., 2009, 2127-2129.

[21] B. K. Cho, H. Y. Park, J. H. Seo, J. Kim, T. J. Kang, B. S. Lee, B. G. Kim, Biotechnol. Bioeng., 2008, 99, 275-284.

[22] H. S. Bea, H. J. Park, S. H. Lee, H. Yun, Chem. Commun., 2011, 47, 5894-5896.

[23] M. S. Malik, E. S. Park, J. S. Shin, Green Chem., 2012, 14, 2137-2140.

[24] S. Arseniyadis, A. Valleix, A. Wangner, C. Mioskowski, Angew. Chem., 2004, 116, 3376-3379.

[25] M. Alexeeva, A. Enright, M. J. Dawson, M. Mahmoudian, N. J. Turner, Angew. Chem. Int. Ed., 2002, 41, 3177-3180.

[26] R. Carr, M. Alexeeva, A. Enright, T. S. C. Eve, M. J. Dawson, N. J. Turner, Angew. Chem. Int. Ed., 2003, 42, 4807-4810.

[27] C. J. Dunsmore, R. Carr, T. Fleming, N. J. Turner, J. Am. Chem. Soc., 2006, 128, 2224-2225.

[28] D. Ghislieri, A. P. Green, M. Pontini, S. C. Willies, I. Rowles, A. Frank, G. Grogan, N. J. Turner, J. Am. Chem. Soc., 2013, 135, 10863-10869.

[29] K. Yasukawa, S. Nakano, Y. Asano, Angew. Chem. Int. Ed., 2014, 53, 4428-4431.

[30] G. Li, J. Ren, P. Yao, Y. Duan, H. Zhang, Q. Wu, J. Feng, P. C. K. Lau, D. Zhu, ACS Catal., 2014, 4, 903-908.

[31] D. Ghislieri, D. Houghton, A. P. Green, S. C. Willies, N. J. Turner, ACS Catal., 2013, 3, 2869-2872.

[32] G. Li, P. Yao, R. Gong, J. Li, P. Liu, R. Lonsdale, Q. Wu, J. Lin, D. Zhu, M. T. Reetz, Chem. Sci., 2017, 8, 4093-4099.

[33] G. A. Aleku, J. Mangas-Sanchez, J. Citoler, S. P .France, S. L. Montgomery, R. S. Heath, M. P. Thompson, N. J. Turner, ChemCatChem, 2018, 10, 515-519.

[34] S. P. France, S. Hussain, A. M. Hill, L. J. Hepworth, R. M. Howard, K. R. Mulholland, S. L. Flitsch, N. J. Turner, ACS Catal., 2016, 6, 3753-3759.

[35] M. Lenz, J. Meisner, L. Quertinmont, S. Lutz, J. Kastner, B. M. Nestl, ChemBioChem, 2017, 18, 253-256.

[36] H. Li, Z. J. Luan, G. W. Zheng, J. H. Xu, Adv. Synth. Catal., 2015, 357, 1692-1696.

[37] H. Li, G. X. Zhang, L. M. Li, Y. S. Ou, M. Y. Wang, C. X. Li, G. W. Zheng, J. H. Xu, ChemCatChem, 2016, 8, 724-727.

[38] J. Mangas-Sanchez, S. P. France, S. L. Montgomery, G. A. Aleku, H. Man, M. Sharma, J. I. Ramsden, G. Grogan, N. J. Turner, Curr. Opin. Chem. Biol., 2017, 37, 19-25.

[39] H. Li, P. Tian, J. H. Xu, G. W. Zheng, Org. Lett., 2017, 19, 3151-3154.

[40] P. Matzel, M. Gand, M. Hohne, Green Chem., 2017, 19, 385-389.
[41] J. M. Zhu, H. Q. Tan, L. Yang, Z. Dai, L. Zhu, H. M. Ma, Z. X. Deng, Z. H. Tian, X. D. Qu, ACS Catal., 2017, 7, 7003-7007.

[42] G. A. Aleku, H. Man, S. P .France, F. Leipold, S. Hussain, L. Toca-Gonzalez, R. Marchington, S. Hart, J. P. Turkenburg, G. Grogan, N. J. Turner, ACS Catal., 2016, 6, 3880-3889.

[43] V. Köhler, Y. M. Wilson, M. Dürrenberger, D. Ghislieri, E. Churakova, T. Quinto, L. Knörr, D. Häussinger, F. Hollmann, N. J. Turner, T. R. Ward, Nat. Chem., 2013, 5, 93-99.

[44] T. Heinisch, M. Pellizzoni, M. Dürrenberger, C. E. Tinberg, V. Köhler, J. Klehr, D. Häussinger, D. Baker, T. R. Ward, J. Am. Chem. Soc., 2015, 137, 10414-10419.

[45] M. Hestericová, M. R. Correro, M. Lenz, P. F. X. Corvini, P. Shahgaldian, T. R. Ward, Chem. Commun., 2016, 52, 9462-9465.

[46] T. Huber, L. Schneider, A. Präg, S. Gerhardt, O. Einsle, M. Müller, ChemCatChem, 2014, 6, 2248-2252.

[47] P. N. Scheller, M. Lenz, S. C. Hammer, B. Hauer, B. M. Nestl, ChemCatChem, 2015, 7, 3239-3242.

[48] D. Wetzl, M. Gand, A. Ross, H. Müller, P. Matzel, S. P. Hanlon, M. Müller, B. Wirz, M. Höhne, H. Iding, ChemCatChem, 2016, 8, 2023-2026.

[49] P. Matzel, M. Gand, M. Höhne, Green Chem., 2017, 19, 385-389.

[50] Z. Maugeri, D. Rother, J. Biothecnol., 2017, 258, 167-170.

[51] D. Koszelewski, I. Lavandera, D. Clay, D. Rozzell, W. Kroutil, Adv. Synth. Catal., 2008, 350, 2761-2766.

[52] M. Höhne, S. Schätzle, H. Jochens, K. Robins, U. T. Bornscheuer, Nat. Chem. Biol., 2010, 6, 807-813.

[53] C. K. Savile, J. M. Janey, E. C. Mundorff, J. C. Moore, S. Tam, W. R. Jarvis, J. C. Colbeck, A. Krebber, F. J. Fleitz, J. Brands, P. N. Devine, G. W. Huisman, G. J. Hughes, Science, 2010, 329, 305-309.

[54] W. Kroutil, E. M. Fischereder, C. S. Fuchs, H. Lechner, F. G. Mutti, D. Pressnitz, A. Rajagopalan, J. H. Sattler, R. C. Simon, E. Siirola, Org. Process Res. Dev., 2013, 17, 751-759.

[55] A. P. Green, N. J. Turner, E. O'Reilly, Angew. Chem. Int. Ed., 2014, 53, 10714-10717.

[56] I. V. Pavlidis, M. S. Weiss, M. Genz, P. Spurr, S. P. Hanlon, B. Wirz, H. Iding, U. T. Bornscheuer, Nat. Chem., 2016, 8, 1076-1082.

[57] G. A. Aleku, S. P. France, H. Man, J. Mangas-Sanchez, S. L. Montgomery, M. Sharma, F. Leipold, S. Hussain, G. Grogan, N. J. Turner, Nat. Chem., 2017, 9, 961-969.

[58] M. J. Abrahamson, E. Vazquez-Figueroa, N. B. Woodall, J. C. Moore, A. S. Bommarius, Angew. Chem. Int. Ed., 2012, 51, 3969-3972.

[59] M. J. Abrahamson, J. W. Wong, A. S. Bommarius, Adv. Synth. Catal., 2013, 355, 1780-1786.

[60] S. K. Au, B. R. Bommarius, A. S. Bommarius, ACS Catal., 2014, 4 4021-4026.

[61] B. R. Bommarius, M. Schurmann, A. S. Bommarius, Chem. Commun., 2014, 50, 14953-14955.

[62] M. P. Thompson, N. J. Turner, ChemCatChem, 2017, 9, 3833-3836.

[63] L. J. Ye, H. H. Toh, Y. Yang, J. P. Adams, R. Snajdrova, Z. Li, ACS Catal., 2015, 5, 1119-1122.

[64] T. Knaus, W. Bohmer, F. G. Mutti, Green Chem., 2017, 19, 453-463.

[65] A. Pushpanath, E. Siirola, A. Bornadel, D. Woodlock, U. Schell, ACS Catal., 2017, 7, 3204-3209.

[66] O. Mayol, S. David, E. Darii, A. Debard, A. Mariage, V. Pellouin, J. L. Petit, M. Salanoubat, V. de Berardinis, A. Zaparucha, C. Vergne-Vaxelaire, Catal. Sci. Technol., 2016, 6, 7421-7428.

[67] F. G. Mutti, T. Knaus, N. S. Scrutton, M. Breuer, N. J. Turner, 
Science, 2015, 349, 1525-1529.

[68] F. F. Chen, Y. Y. Liu, G. W. Zheng, J. H. Xu, ChemCatChem, 2015, 7, 3838-3841.

[69] F. F. Chen, G. W. Zheng, L. Liu, H. Li, Q. Chen, F. L. Li, C. X. Li, J. H. Xu, ACS Catal., 2018, 8, 2622-2628.

[70] F. Yang, X. Zhang, F. Li, Z. Wang, L. Wang, Eur. J. Org. Chem.,
2016, 2016, 1251-1254.

[71] F. Yang, Z. Wang, X. Zhang, L. Jiang, Y. Li, L. Wang, ChemCatChem, 2015, 7, 3450-3453.

[72] A. Rodríguez, A. Guerrero, H. Gutierrez-de-Terán, D. Rodríguez, J. Brea, M. I. Loza, G. Rosell, M. P. Bosch, MedChemComm, 2015, 6, 1178-1185.

\title{
Brevibacterium epidermidis催化酮不对称还原胺化合成(S)-手性胺
}

\author{
李清华 ${ }^{\mathrm{a}}$, 董 源 ${ }^{\mathrm{b}}$, 陈飞飞 $\mathrm{a}^{\mathrm{a}}$, 柳 䂞 ${ }^{\mathrm{a}}$, 李春秀 ${ }^{\mathrm{a}}$, 许建和 ${ }^{\mathrm{a}}$, 郑高伟 ${ }^{\mathrm{a}}{ }^{*}$ \\ a华东理工大学生物反应器工程国家重点实验室, 上海200237 \\ $\mathrm{b}$ 中国人民解放军第三 $\bigcirc$ 二医院药学部, 北京 100039
}

\begin{abstract}
摘要: 光学纯手性胺是一类非常重要的手性化学品, 作为手性砌块和手性拆分剂广泛用于医药、农业化学品、精细化学品 等产品的合成中. 据统计, 美国FDA近年来批准的约 $40 \%$ 药物中都含有一个或多个手性胺结构单元. 胺脱氢酶(AmDH)是 由氨基酸脱氢酶改造而来的一类催化酮不对称还原胺化的新酶, 其在手性胺的合成中展现出较强的潜力, 已引起国内外学 术界和工业界的广泛关注. 这是因为该酶能够利用廉价的无机铵为胺供体, 且具有催化效率高、原子经济性好和环境友好 等优点. 迄今为止已经有数个高效的胺脱氢酶被成功开发和报道, 但是这些通过蛋白质工程改造的胺脱氢酶均为 $(R)$-选择 性, 因此只能合成 $(R)$-选择性的手性胺, 遗憾的是还未见有 $(S)$-选择性胺脱氢酶的报道. 因此, 本文主要目的是期望从自然 环境中鉴定能够不对称还原胺化酮合成(S)-手性胺的微生物, 进而从中分离得到能够以无机铵作为胺供体合成(S)-手性胺 的(S)-选择性酶.

本文首先利用苯乙胺作为唯一氮源, 从土壤中篮选能够利用苯乙胺生长的菌株, 进而利用苯乙酮作为初篮底物对得到 的菌株进行胺化能力笁选, 再利用(4-氟苯基)丙酮作为模式底物进行进一步的篮选. 幸运的是, 我们获得了能够利用无机 铵作为胺供体催化(4-氟苯基)丙酮不对称还原胺化合成(S)-4-氟- $\alpha$-甲基苯乙胺的菌株, 经过16S RNA鉴定为表皮短杆菌, 命 名为B. epidermidis ECU1015.

接下来, 我们对 B. epidermidis ECU1015催化的胺化反应中的关键参数如胺基供体及其最适浓度、反应温度、 $\mathrm{pH}$ 值和 底物浓度等进行了优化, 确定最佳反应条件: 胺供体为 $\mathrm{NH}_{4} \mathrm{Cl}(1.25 \mathrm{~mol} / \mathrm{L})$, 反应温度为 $30{ }^{\circ} \mathrm{C}, \mathrm{KPB}$ 缓冲液 $(200 \mathrm{mmol} / \mathrm{L}, \mathrm{pH}$ 7.5), 底物浓度 $10 \mathrm{mmol} / \mathrm{L}$. 最后, 在最适的反应条件下, 我们对B. epidermidis ECU1015催化的底物谱进行了研究. 结果表 明, 该微生物不能催化大位阻芳香酮和链状酮的胺化, 对位阻较小的苯乙酮及(4-氟苯基)丙酮具有较好的还原胺化能力, 而 且对苯环上带有吸电子取代基的酮化合物具有更好的转化效果. 经手性分析, 所有生成的手性胺均为 $(S)$-构型, 产品的光 学纯度均 $>99 \%$.

B. epidermidis催化酮不对称胺化所形成的产物构型均为 $(S)$-选择性, 这不同于已报道的 $(R)$-选择性胺脱氢酶. 该菌株的 发现为(S)-选择性胺脱氢酶的进一步鉴定奠定了一定的研究基础, 相关蛋白的分离纯化工作正在进行.
\end{abstract}

关键词: 生物催化; 还原胺化; 不对称合成; 潜手性酮; 手型胺

收稿日期: 2018-04-30. 接受日期: 2018-05-24. 出版日期: 2018-10-05.

*通讯联系人. 电话/传真: (021) 64250840; 电子信箱: gaoweizheng@ecust.edu.cn

基金来源:国家自然科学基金(21472045, 21536004); 国防科技创新特区项目(17-163-12-ZT-003-055-01).

本文的电子版全文由Elsevier出版社在ScienceDirect上出版(http://www.sciencedirect.com/science/journal/18722067). 